\title{
ANALISIS PENGGUNAAN LAHAN DAN ARAHAN PENGENDALIAN PEMANFAATAN RUANG DI KABUPATEN BOGOR
}

\author{
Analysis of Land Use and Control Direction of Spatial Usage in Bogor \\ Regency
}

\section{Ely Triwulan Dani ${ }^{1}$, Santun R.P. Sitorus ${ }^{2}$ dan Khursatul Munibah}

\begin{abstract}
Abstrak: Tujuan utama dari penelitian ini adalah untuk merumuskan arahan pengendalian pemanfaatan ruang di Kabupaten Bogor. Analisis spasial digunakan untuk mendapatkan informasi tentang penggunaan lahan, kepemilikan lahan, izin lokasi, dan evaluasi penggunaan lahan terhadap rencana pola ruang. Metode Skalogram digunakan untuk menentukan tingkat hirarki wilayah, dan faktor-faktor yang mempengaruhi inkonsistensi penggunaan lahan terhadap rencana pola ruang diperoleh dari analisis data lapang. Perumusan arahan pengendalian pemanfaatan ruang diperoleh dengan analisis deskriptif. Hasil penelitian menunjukkan bahwa 51,33\% dari penggunaan lahan eksisting di Kabupaten Bogor belum terlaksana dan masih bisa diarahkan agar sesuai dengan rencana pola ruang, sisanya 38,06\% adalah sesuai dan tidak sesuai $10,62 \%$. Faktorfaktor yang menyebabkan inkonsistensi tersebut adalah kurangnya sosialisasi kepada masyarakat, tidak adanya perizinan, kebutuhan tempat tinggal, adanya fasilitas umum dan aksesibilitas, penggunaan lahan telah ada sebelum rencana pola ruang ditetapkan, berpindahnya kepemilikan lahan, dan fasilitas pertanian kurang mendukung. Implikasi dari hasil ini perlu untuk menerapkan empat instrumen pengendalian, diantaranya adalah perizinan, peraturan zonasi, pemberian insentif dan disinsentif, dan sanksi. Selain itu, perlunya sosialisasi kebijakan serta pengawasan, monitoring dan evaluasi secara berkala.
\end{abstract}

Kata kunci: arahan pengendalian, inkonsistensi, penggunaan lahan, rencana pola ruang

\begin{abstract}
The main purpose of this study was to formulate the control direction of spatial usage in Bogor Regency. The spatial analysis used to obtain information on land use, land ownership, location permits, and evaluation of land use on spatial pattern plan. Schallogram method used to determine the level of the hierarchy of the region, and factors affecting the inconsistency of land use on spatial pattern plan obtained by the analysis of field data. Formulation of the directives controlling spatial utilization is obtained by descriptive analysis. The results showed that $51.33 \%$ of exsisting land use in Bogor Regency has not been done and still can be directed in order to conform with the spatial pattern plan, the remaining $38.06 \%$ was suitable and unsuitable $10.62 \%$. The factors that cause such inconsistency were the lack socialization policy less, the absence of licensing, housing needs, public facilities availability and accessibility, lands of usage before defined spatial pattern plan, the transfer of land ownership, and sortage of agricultural support facilities. The implications of these results were necessary to apply four control instruments, those are licensing, zoning regulations, provision of incentives and disincentives, and sanctions. Besides, the need for policy dissemination and surveillance, monitoring and evaluation periodically.
\end{abstract}

Keywords: control direction, inconsistency, land use, spatial pattern plan

\footnotetext{
${ }^{1}$ Program Studi Ilmu Perencanaan Wilayah, Sekolah Pascasarjana, Institut Pertanian Bogor

${ }^{2}$ Departemen Ilmu Tanah dan Sumberdaya Lahan, Fakultas Pertanian, Institut Pertanian Bogor
}

Korespondensi: elmartptk@gmail.com 


\section{PENDAHULUAN}

Kabupaten Bogor merupakan bagian dari Kawasan Strategis Nasional (KSN) Jabodetabekpunjur, sebagai daerah hulu wilayah Bogor, Puncak dan Cianjur (Kawasan Bopunjur) diarahkan sebagai kawasan konservasi. Secara geopolitik kawasan Jabodetabekpunjur menjadi gambaran sistem negara, dimana keberhasilan pengelolaan pembangunan di Jabodetabekpunjur merupakan cerminan keberhasilan pembangunan di Indonesia (Djakapermana, 2008). Saat ini Kabupaten Bogor berperan dalam tiga fungsi strategis yaitu: (1) sebagai penyangga DKI Jakarta, berupa pengembangan pemukiman perkotaan sebagai bagian dalam sistem Metropolitan Jabodetabek, (2) merupakan daerah konservasi dalam tata air untuk Metropolitan Jabodetabek, dan (3) merupakan daerah pengembangan pertanian, khususnya hortikultura (Pemda. Kab. Bogor, 2016). Fenomena umum yang terjadi di kawasan metropolitan Jabodetabek adalah terjadinya perluasan areal lahan terbangun yang tidak terkendali yang dipicu oleh jaringan jalan (Barus et al., 2011) dan kondisi aksesibilitas yang baik (Zain et al., 2013). Demikian halnya yang terjadi di Kabupaten Bogor meski wilayahnya berperan sebagai kawasan konservasi, namun perubahan pemanfaatan ruang, kegiatan sosial ekonomi dan kelembagaan telah berjalan dengan dinamis (Fajarini et al., 2015).

Sektor industri memegang peranan penting dalam peningkatan pembangunan ekonomi di Kabupaten Bogor. Data BPS menyebutkan nilai PDRB atas dasar harga berlaku di Kabupaten Bogor tahun 2014 menunjukkan sektor industri berperan sebesar 55,23 persen dengan laju pertumbuhan sebesar 5,83 persen. Dari segi jumlah penduduk, Kabupaten Bogor merupakan Kabupaten yang memiliki populasi tertinggi di Indonesia, dengan laju pertumbuhan 3,16 persen. Kondisi tersebut semakin memicu meningkatnya perubahan penggunaan lahan di Kabupaten Bogor yang tidak terkendali. Selain itu, industri dan berbagai kegiatan usaha yang tumbuh subur menyebabkan terjadinya konversi lahan terutama dari penggunaan lahan pertanian menjadi non-pertanian yang berakibat pada terjadinya pelanggaran terhadap pola ruang Rencana Tata Ruang Wilayah (RTRW).

Inkonsistensi penggunaan lahan terhadap RTRW dikhawatirkan dapat menurunkan kemampuan fisik lahan tersebut serta dapat mengancam keberlanjutan sumberdaya (Kurnianti, 2015). Berdasarkan data dari Kantor BPN Provinsi Jawa Barat, kesesuaian penggunaan lahan dengan pola ruang RTRW di Kabupaten Bogor pada tahun 2011 adalah sekitar 46,69 persen sedangkan sisanya 53,31 persen tidak sesuai (Kanwil. BPN Prov. Jawa Barat, 2013). Sementara itu, Mayasary (2015) menyebutkan antara tahun 2005-2012 penggunaan lahan di Kota Bogor sebesar 59,05 persen tidak sesuai dengan pola ruang RTRW dan 40,95 persen telah sesuai. Besarnya angka ketidaksesuaian penggunaan lahan dengan RTRW menunjukkan bahwa pemanfaatan lahan di Kabupaten Bogor harus dikendalikan untuk mewujudkan terciptanya pembangunan yang tertib tata ruang.

Saat ini salah satu perangkat utama dalam pengendalian pemanfaatan ruang untuk menekan konversi lahan adalah RTRW dan mekanisme perizinan (Bakar, 2008), dimana perizinan ini sebagai salah satu strategi pemerintah dalam melindungi penggunaan lahan sawah (Mansur, 2015). Salah satu bentuk perizinan yang dapat menjadi instrumen pengendalian adalah izin lokasi (Dewi, 2011), yang merupakan salah satu faktor yang berpengaruh terhadap peningkatan perubahan penggunaan lahan dari pertanian menjadi non-pertanian (Fajarini et al., 2015).

Sejalan dengan Undang-Undang Nomor 32 Tahun 2004 tentang Pemerintahan Daerah, maka Pemerintah Provinsi dan Kabupaten/Kota sebagai daerah otonom telah diberikan kewenangan urusan pemerintahan dan sekaligus menjadi kewajiban untuk mengatur dan mengurus perencanaan, pemanfaatan dan pengawasan tata ruang di Daerah. Pengendalian pemanfaatan ruang di daerah harus dilakukan secara terpadu. Oleh sebab itu, dalam proses pengendalian pemanfaatan ruang harus dilakukan oleh berbagai 
lembaga/instansi yang berwenang sesuai dengan otorisasinya (Bakar, 2008). Salah satu instansi yang dapat berperan dalam mendukung pengendalian pemanfaatan ruang adalah Badan Pertanahan Nasional (BPN). Firman (2004) menyebutkan bahwa dinamika perubahan lahan banyak dipengaruhi oleh kebijakan BPN dalam perizinan pengusahaan lahan.

Tujuan utama penelitian ini adalah menyusun arahan pengendalian pemanfaatan ruang di Kabupaten Bogor, dengan beberapa tujuan antara yaitu: (1) Menganalisis jenis penggunaan lahan, kepemilikan lahan, izin lokasi, dan tingkat hirarki wilayah Kabupaten Bogor, (2) Mengevaluasi kesesuaian penggunaan lahan terhadap rencana pola ruang Kabupaten Bogor, dan (3) Mengidentifikasi faktor-faktor yang mempengaruhi inkonsistensi penggunaan lahan terhadap rencana pola ruang di Kabupaten Bogor.

\section{METODE PENELITIAN}

\section{Lokasi dan Waktu Penelitian}

Penelitian dilaksanakan di Kabupaten Bogor, Provinsi Jawa Barat yang terdiri dari 40 kecamatan (Gambar 1). Secara geografis wilayah Kabupaten Bogor terletak pada titik koordinat 6 $6^{\circ} 18^{\prime} 10^{\prime \prime}-6^{\circ} 47^{\prime} 10^{\prime \prime}$ Lintang Selatan dan $106^{\circ} 23^{\prime} 45^{\prime \prime}-107^{\circ} 13^{\prime} 30^{\prime \prime}$ Bujur Timur. Penelitian dilaksanakan pada bulan Oktober 2015 sampai dengan Agustus 2016.

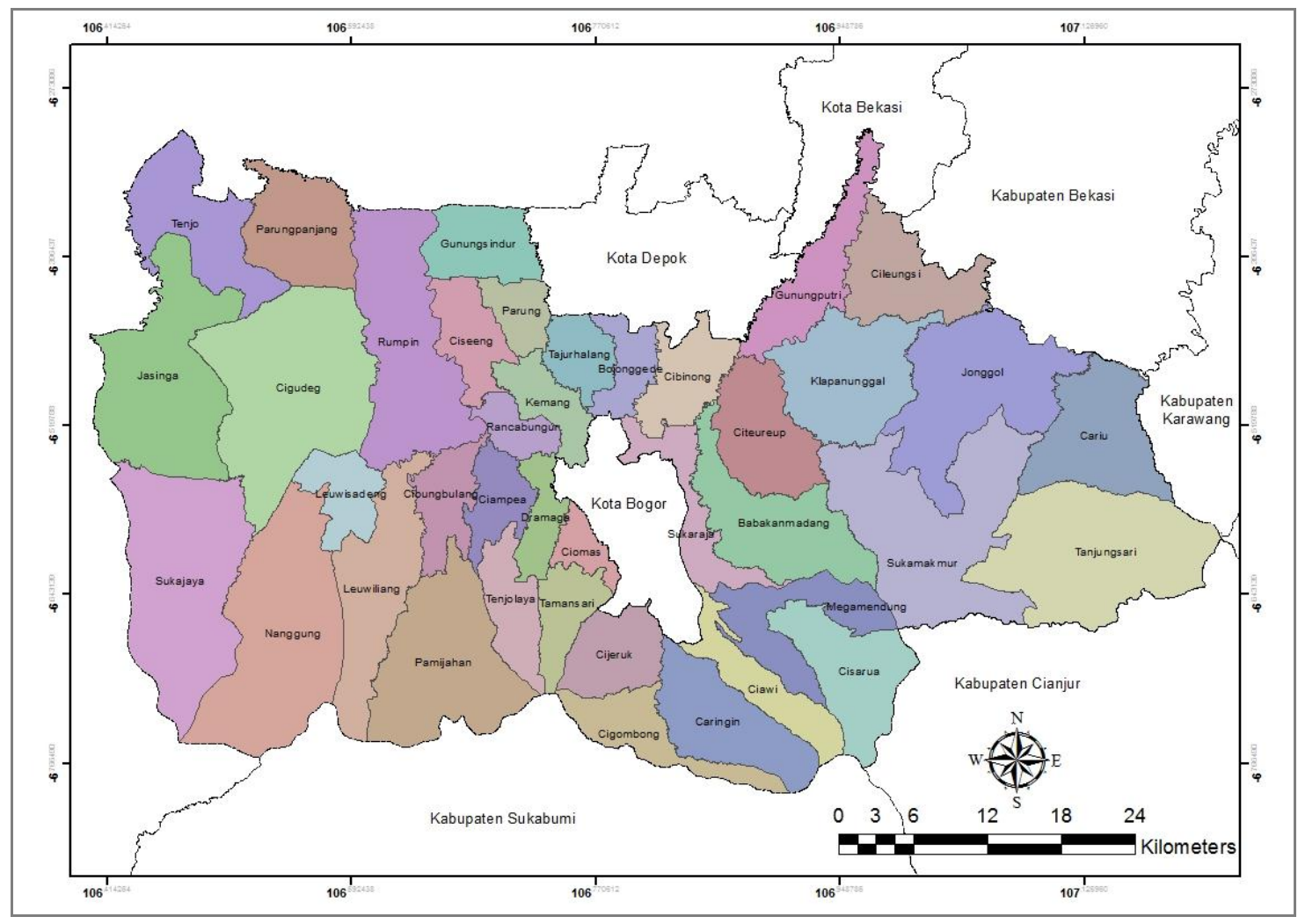

Gambar 1. Peta Lokasi Penelitian 


\section{Jenis dan Sumber Data}

Data yang digunakan dalam penelitian berupa data primer dan data sekunder. Data primer diperoleh dari survei dan wawancara lapang untuk mengamati jenis penggunaan lahan dan memperoleh variabel-variabel inkonsistensi penggunaan lahan terhadap rencana pola ruang. Wawancara lapang dilakukan dengan teknik Sampling Nonprobabilitas melalui pendekatan Purposive Sampling, responden wawancara adalah masyarakat/aparat/tokoh masyarakat. Wawancara juga dilakukan pada Bappeda dan BPN Kabupaten Bogor untuk mendapatkan gambaran penggunaan lahan dan pengendalian pemanfaatan ruang di kabupaten Bogor.

Data sekunder terdiri dari dokumen perencanaan, peraturan perundang-undangan, data spasial (peta-peta, citra satelit), buku, jurnal, arsip, serta laporan penelitian. Data sekunder terdiri dari Dokumen dan Peta RTRW Kabupaten Bogor tahun 2005-2025 skala 1:25.000, Peta Administrasi Kabupaten Bogor skala 1:25.000, Peta Penggunaan Lahan Kabupaten Bogor tahun 2013 skala 1:25.000, Citra IKONOS Kabupaten Bogor tahun 2014, data Potensi Desa Kabupaten Bogor tahun 2015, Peta Bidang Lahan/Hak Kepemilikan Lahan (BPN) Kabupaten Bogor skala 1:25.000, serta Peta Izin Lokasi tahun 2000-2015 skala 1:25.000.

\section{Metode Analisis Data}

\section{Analisis Penggunaan Lahan, Kepemilikan Lahan, dan Izin Lokasi}

Gambaran karakteristik penggunaan lahan, kepemilikan lahan, dan izin lokasi diawali dengan melakukan overlay dengan peta batas administrasi wilayah Kabupaten Bogor. Penggunaan lahan kabupaten Bogor tahun 2015 diperoleh dari hasil edit Peta Penggunaan Lahan Tahun 2013, yaitu digitasi on screen dengan citra IKONOS tahun 2014 dengan melakukan interpretasi visual didukung survei lapang.

Analisis kepemilikan lahan dilakukan dengan mengedit peta bidang lahan tahun 2015, dimana sebelumnya dianalisis luas kawasan hutan dan Areal Penggunaan Lain (APL). Selanjutnya dari APL tersebut dianalisis hak-hak kepemilikan lahan yang telah terdaftar di BPN kemudian dikelompokkan berdasarkan jenis hak kepemilikan lahan untuk satu kabupaten dan masing-masing kecamatan.

Analisis izin lokasi dilakukan dengan mengedit peta izin lokasi dari tahun 2000 sampai dengan 2015 untuk mendapatkan sebaran izin lokasi di Kabupaten Bogor. Selanjutnya mengelompokkan jenis izin lokasi dalam beberapa peruntukan, yaitu: perumahan; bisnis/usaha ekonomi, agrowisata, industri dan pergudangan, pertambangan, pendidikan, pertanian, peternakan, perkebunan, dan lain-lain.

\section{Analisis Hirarki Wilayah}

Analisis hirarki wilayah menggunakan metode skalogram digunakan untuk melihat tingkat hirarki perkembangan wilayah berdasarkan jumlah ketersediaan fasilitas, luas wilayah, jumlah penduduk serta jarak tempuh wilayah ke pusat pelayanan (Panuju dan Rustiadi, 2013). Data yang digunakan adalah data PODES yang diperoleh dari BPS, dengan menggunakan rumus (Panuju dan Rustiadi, 2013):

$$
\mathrm{K} i \boldsymbol{j}=\frac{(\mathrm{X} i \boldsymbol{j}-\min (\mathrm{X} \boldsymbol{j}))}{\mathrm{S} j}
$$

Dimana:

Kij : nilai baku untuk desa/kelurahan ke-i dan jenis fasilitas ke-j,

Xij : bobot indeks penciri untuk desa/kelurahan ke-i dan jenis fasilitas ke-j, 
$\min (\mathrm{Xj}) \quad$ : nilai minimum indeks fasilitas ke-j, dan

Sj $\quad$ : nilai standar deviasi

Penentuan hirarki didasarkan pada nilai standar deviasi, Indeks Perkembangan Kecamatan (IPK), dan nilai rataannya. Nilai yang didapat untuk selang hirarki, digunakan untuk menentukan kelas hirarki. Kriteria pengelompokannya adalah sebagai berikut: (1) Kelas hirarki I (tinggi), jika IPK lebih besar dari nilai simpangan baku (standar deviasi) dan nilai rata-rata; (2) Kelas Hirarki II (sedang), jika nilai IPK lebih besar atau sama dengan nilai rata-rata; dan (3) Kelas Hirarki III (rendah), jika nilai IPK lebih kecil dari rata-rata (Panuju dan Rustiadi, 2013).

\section{Evaluasi Kesesuaian dan Analisis Faktor-faktor Inkonsistensi}

Analisis kesesuaian penggunaan lahan eksisting terhadap rencana pola ruang RTRW Kabupaten Bogor dilakukan dengan meng-overlay peta penggunaan lahan tahun 2015 dengan peta rencana pola ruang RTRW Kabupaten Bogor tahun 2005-2025. Hasil analisis ini menghasilkan tiga jenis kesesuaian, yaitu penggunaan lahan yang sudah sesuai maupun tidak sesuai dengan rencana pola ruang, serta rencana pola ruang yang belum terlaksana sehingga penggunaan lahan masih dapat berubah sesuai dengan rencana pola ruang. Analisis kesesuaian berdasarkan pertimbangan jenis penggunaan lahan yang irreversible (sulit/tidak dapat diubah) baik terkait biaya maupun upaya yang akan dilakukan, permasalahan-permasalahan sosial yang akan timbul, serta fungsi Kabupaten Bogor sebagai kawasan konservasi.

Analisis faktor-faktor yang mempengaruhi inkonsistensi penggunaan lahan terhadap rencana pola ruang diperoleh dengan melakukan wawancara lapang pada pengunaan lahan yang inkonsisten dengan rencana pola ruang. Variabel hasil wawancara dipersentasekan berdasarkan frekuensi masing-masing variabel terhadap keseluruhan jumlah responden.

\section{Arahan Pengendalian Pemanfaatan Ruang}

Arahan pengendalian pemanfaatan ruang dengan melakukan analisis deskriptif yang dibangun dari keseluruhan hasil analisis dan disusun berdasarkan 4 instrumen pengendalian pemanfaatan ruang yaitu: peraturan zonasi, perizinan, pemberian insentif dan disinsentif, serta pemberian sanksi.

\section{HASIL DAN PEMBAHASAN}

\section{Gambaran Jenis Penggunaan Lahan, Kepemilikan Lahan, Izin Lokasi, dan Tingkat Hirarki Wilayah Kabupaten Bogor}

Penggunaan lahan Kabupaten Bogor tahun 2015 berdasarkan urutan luasan yaitu berupa sawah (22,66\%), perkebunan (19,8\%), permukiman (16,77\%), semak/belukar/lahan kosong $(14,19 \%)$, tegalan $(13,16 \%)$, hutan $(11,15 \%)$, industri $(1,36 \%)$, dan tubuh air $(0,91 \%)$. Luas terbesar penggunaan lahan sawah terdapat di Kec. Jonggol, Sukamakmur, dan Cariu; tegalan di Kec. Sukamakmur; sedangkan perkebunan di Kec. Jasinga. Hutan didominasi oleh hutan lebat yang sebagian besar berupa hutan lindung yang tersebar luas di bagian selatan. Permukiman yang mendominasi berupa kampung padat dengan luasan tertinggi terdapat di Gunung Putri, sedangkan luasan industri terbesar terdapat di Kec. Kelapanunggal, Citeureup, Cileungsi, dan Gunung Putri. Hasil analisis berupa peta penggunaan lahan Kabupaten Bogor tahun 2015 seperti disajikan pada Gambar 2. 


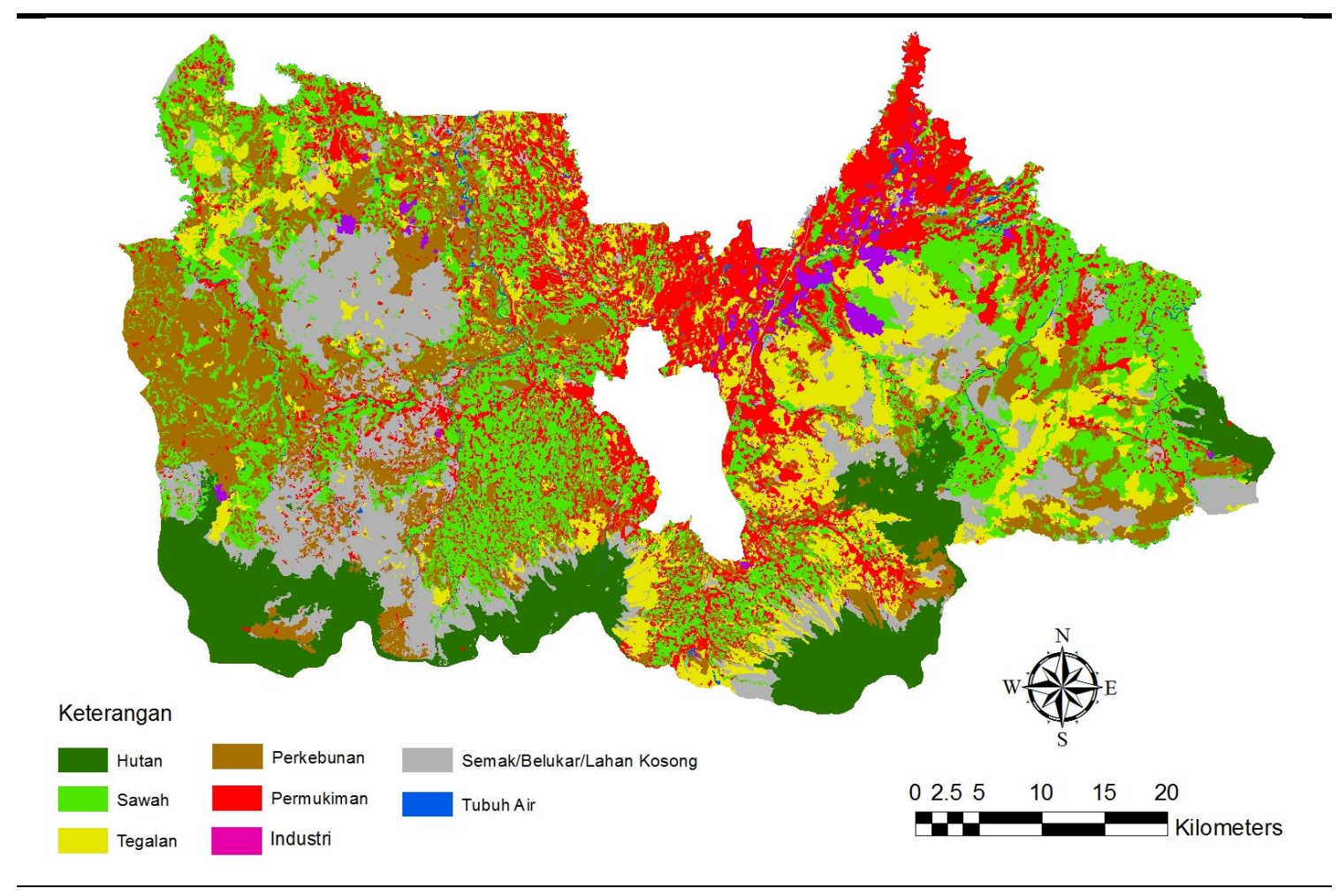

Gambar 2. Peta Penggunaan Lahan Kabupaten Bogor Tahun 2015

Hasil analisis kepemilikan lahan seperti disajikan pada Gambar 3, luas Areal Penggunaan Lain (APL) Kabupaten Bogor sebesar 71,88\%, dimana sampai tahun 2015 sebesar 38\% sudah memiliki sertipikat kepemilikan lahan dengan jenis hak berupa Hak Milik (51,80\%), Hak Guna Bangunan (21,49\%), Wakaf (10,55\%), Hak Pakai $(2,64 \%)$ dan jenis hak lainnya (13,52\%). Luasan Hak Milik terbesar di Kec. Sukamakmur, luasan Hak Guna Bangunan terbesar di Kec. Parung, luasan Hak Pakai terbesar di Kec. Kelapanunggal, dan wakaf terluas di Kec. Sukamakmur. Peta kepemilikan lahan Kabupaten Bogor tahun 2015 seperti disajikan pada Gambar 4.

Luas area izin lokasi Kabupaten Bogor dari tahun 2000-2015 adalah 32,818 ha atau sekitar $11 \%$ dari keseluruhan luas Kabupaten Bogor. Berdasarkan luas peruntukannya diurutkan sebagai berikut: perumahan $(57,21 \%)$, bisnis dan usaha perekonomian $(13,17 \%)$, agrowisata $(11,74 \%)$, industri dan pergudangan (3.66\%), pertambangan $(1,97 \%)$, pendidikan $(1,93 \%)$, pertanian $(0,597 \%)$, peternakan $(0,54 \%)$, perkebunan $(0,38 \%)$, dan sisanya untuk kegiatan lainnya, seperti disajikan pada Gambar 5. Peta sebaran izin lokasi di Kabupaten Bogor tahun 2000-2015 seperti disajikan pada Gambar 6.

Hasil perhitungan analisis skalogram menghasilkan 8 kecamatan tergolong hirarki I (Leuwiliang, Cisarua, Cibinong, Cariu, Ciawi, Babakan Madang, Nanggung, dan Pamijahan); 12 kecamatan tergolong hirarki II (Jonggol, Tanjungsari, Parung, Tamansari, Gunung Sindur, Ciampea, Cileungsi, Kelapa Nunggal, Jasinga, Tenjolaya, Caringin, dan Ciomas); dan 20 kecamatan tergolong hirarki III (Ranca Bungur, Cigudeg, Cigombong, Tenjo, Cijeruk, Sukaraja, Leuwisadeng, Dramaga, Cibungbulang, Parung Panjang, Megamendung, Gunung Putri, Tajur Halang, Citeureup, Bojong Gede, Kemang, Ciseeng, Sukamakmur, Rumpin, dan Sukajaya). Kecamatan berhirarki I berarti lebih mampu melayani kebutuhan masyarakat sekitar dengan aksesibilitas yang terjangkau dan mudah dibandingkan dengan kecamatan lainnya. Selain jumlah dan aksesibilitas fasilitas, nilai 
Indeks Perkembangan Kecamatan (IPK) sangat dipengaruhi oleh jumlah penduduk. Kecamatan Cibinong sebagai ibukota kabupaten berada di urutan ke-tiga, padahal jumlah fasilitas dan jumlah jenis fasilitas di kecamatan Cibinong lebih tinggi dibandingkan dengan dua kecamatan yang berada di urutan ke-satu dan ke-dua. Hal ini karena jumlah penduduk yang dilayani di kecamatan Cibinong jauh lebih besar hampir tiga kali lipat dari kecamatan Leuwiliang dan Cisarua. Hasil analisis tingkat hirarki wilayah berupa peta hirarki wilayah seperti disajikan pada Gambar 7.

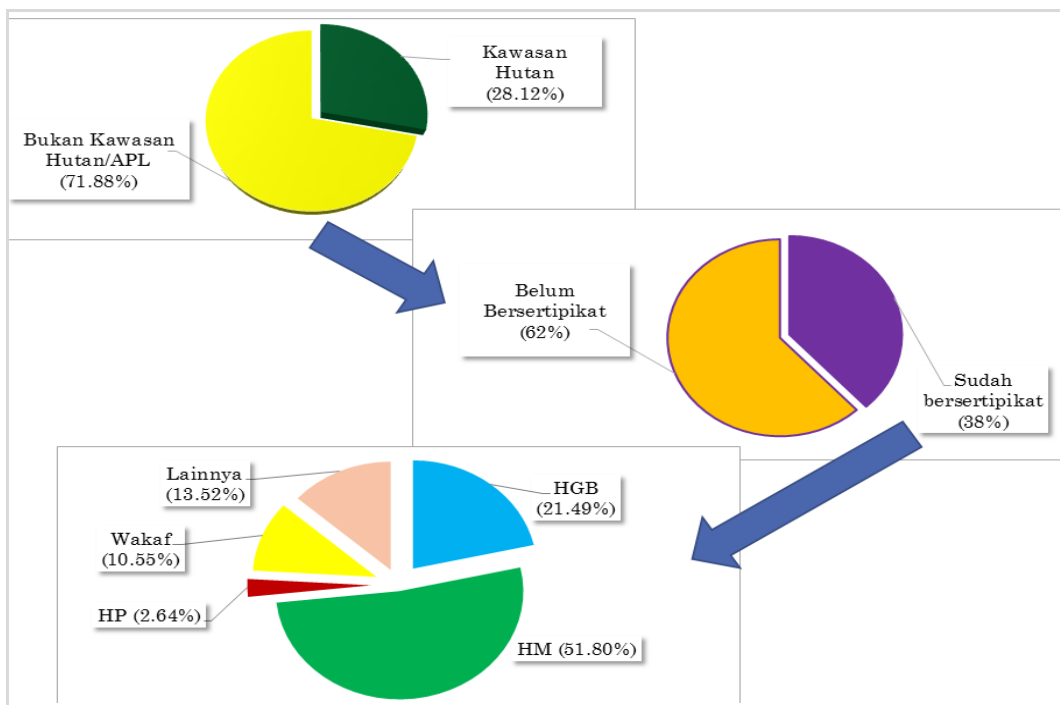

Keterangan: APL (Areal Penggunaan Lain), HM (Hak Milik), HGB (Hak Guna Bangunan), HP (Hak Pakai)

\section{Gambar 3. Hasil Analisis Kepemilikan Lahan}

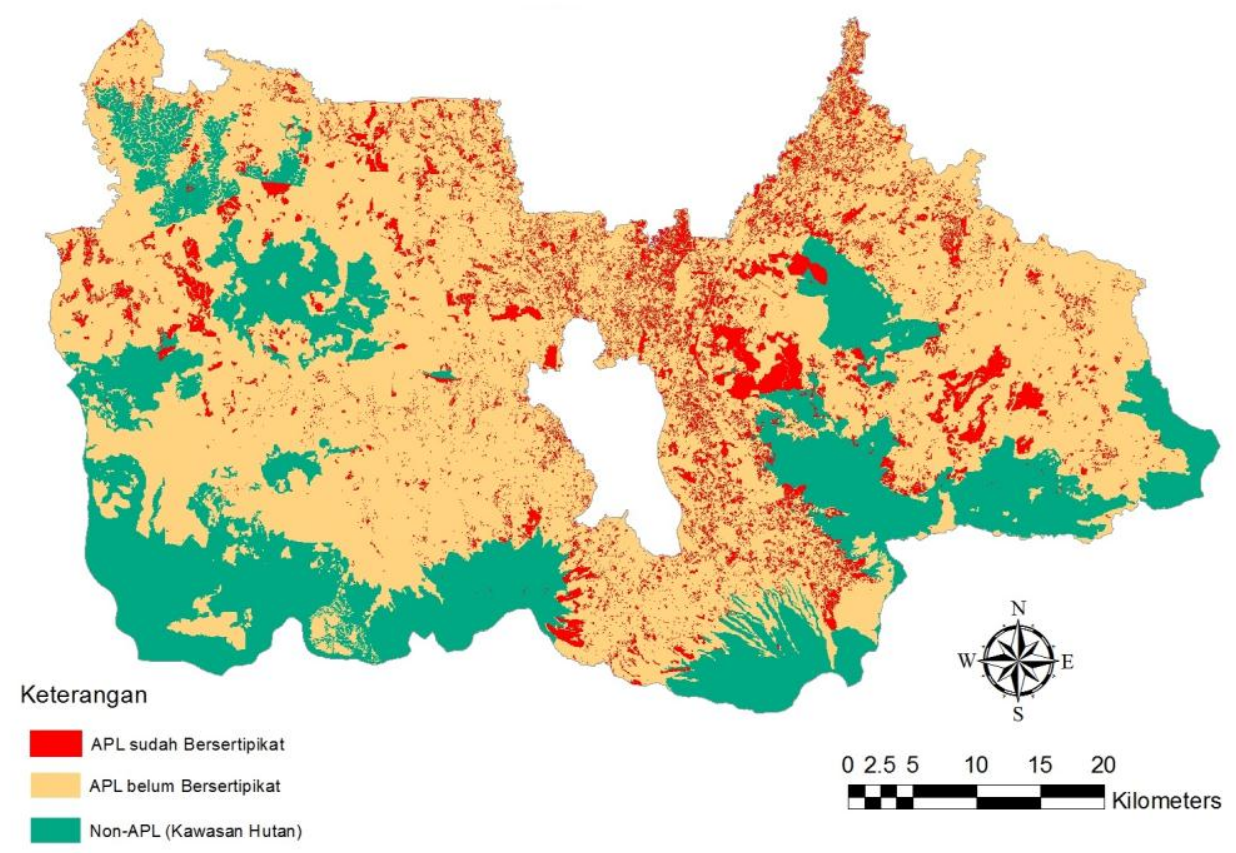

Gambar 4. Peta Sebaran Kepemilikan Lahan Kabupaten Bogor Tahun 2015 


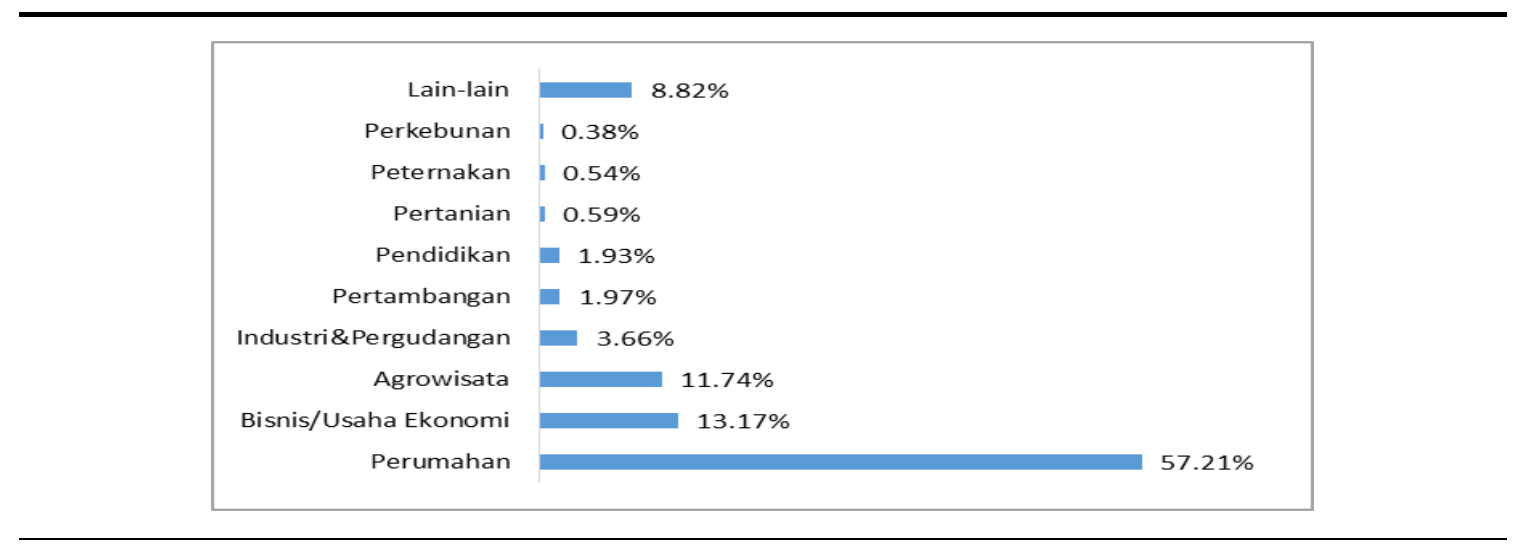

Gambar 5. Persentase Peruntukan Izin Lokasi di Kabupaten Bogor Tahun 2000-2015

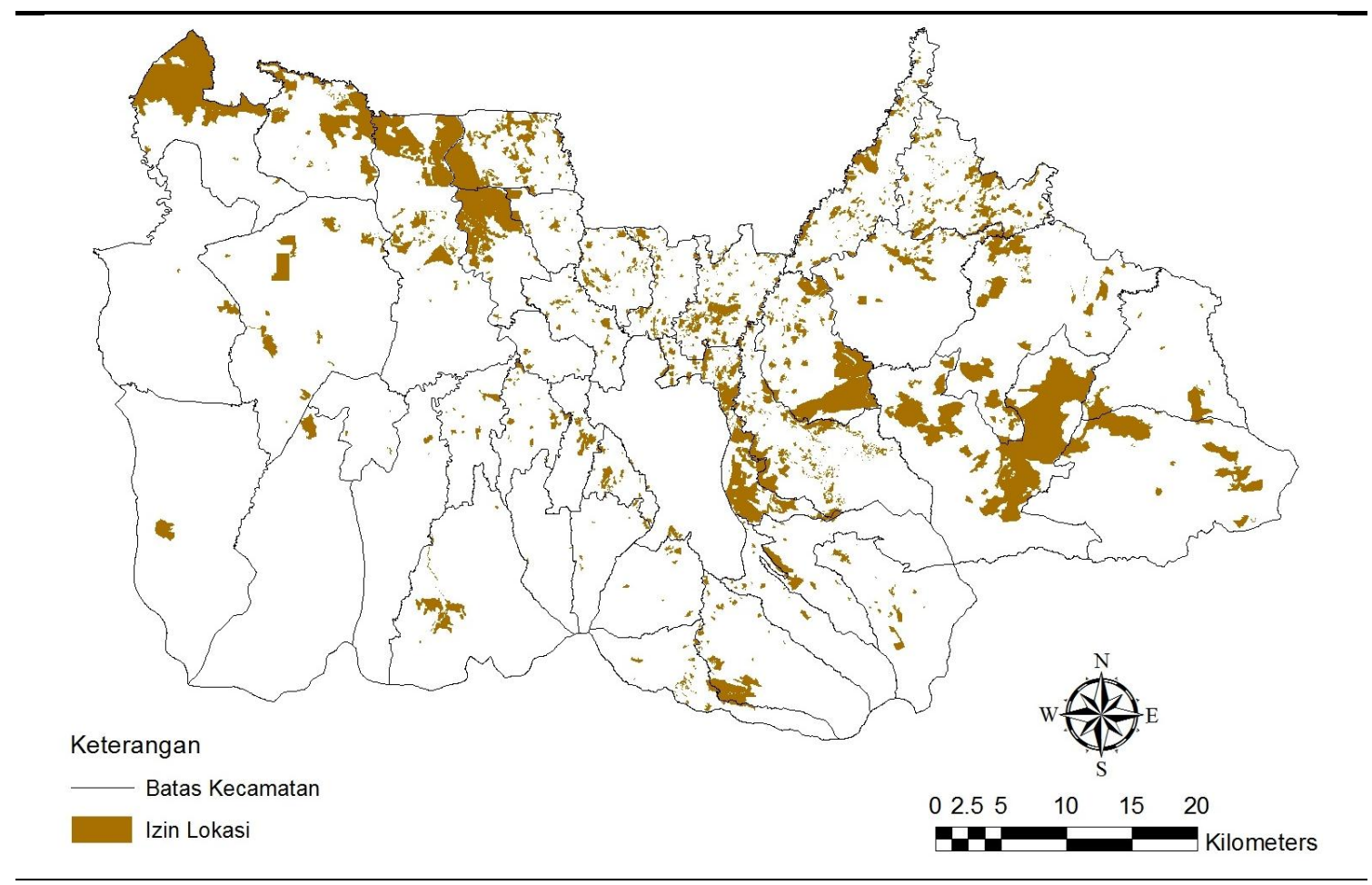

Gambar 6. Peta Sebaran Izin Lokasi di Kabupaten Bogor Tahun 2000-2015

\section{Evaluasi Kesesuaian Penggunaan Lahan terhadap Rencana Pola Ruang}

Hasil tumpang susun peta penggunaan lahan dengan peta rencana pola ruang disajikan pada Gambar 8 dan Tabel 1. Dari Gambar 8 dapat dilihat kawasan hutan, kawasan permukiman, kawasan industri, dan tubuh air masih memerlukan area tambahan untuk memenuhi rencana luasan dalam pola ruang. Sementara itu, rencana luas kawasan pertanian lahan basah, kawasan pertanian lahan kering, dan kawasan perkebunan sudah terpenuhi dari luas penggunaan eksisting, sedangkan penggunaan lahan eksisting berupa semak/belukar/lahan kosong dapat dialihkan untuk penggunaan lain yang luasannya belum terpenuhi. 


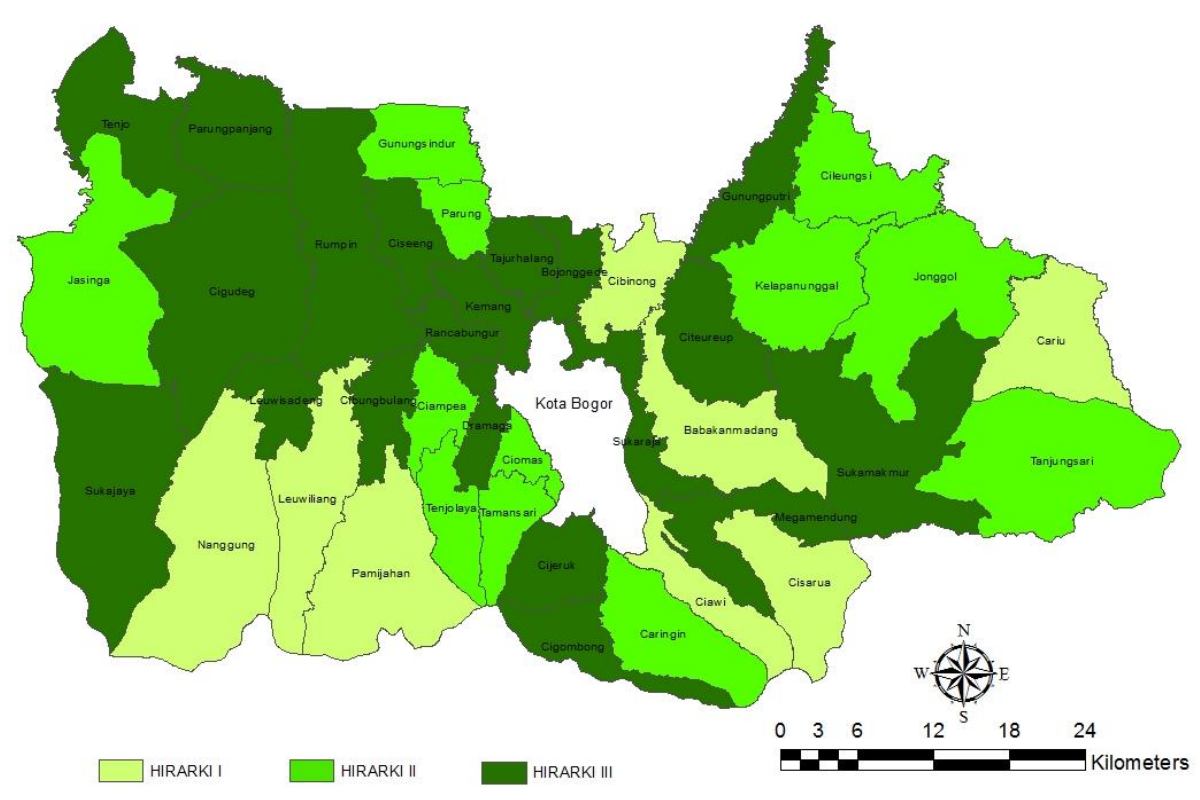

Gambar 7. Peta Hirarki Wilayah Kabupaten Bogor Tahun 2015

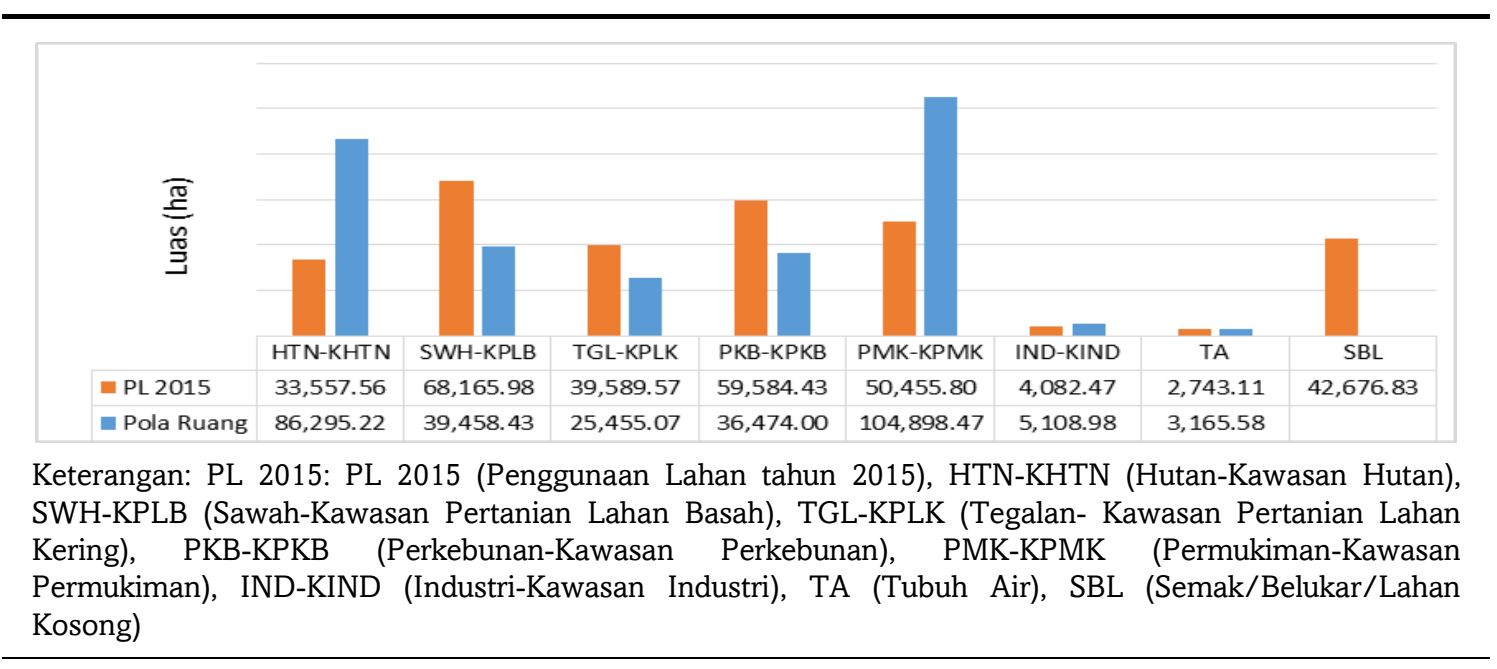

Gambar 8. Grafik Perbandingan Luas Penggunaan Lahan dan Rencana Pola Ruang

Dari Tabel 1 diperoleh hasil penggunaan lahan yang sesuai dengan rencana pola ruang seluas $114.493,46$ ha $(38,06 \%)$, penggunaan lahan yang tidak sesuai dengan rencana pola ruang seluas $31.946,93$ ha $(10,62 \% \%)$, sisanya belum terlaksana dan penggunaan lahan masih dapat berubah sesuai dengan rencana pola ruang seluas 154.415,36 ha $(51,33 \%)$. Luas kesesuaian tertinggi terdapat di Kec. Cibinong sedangkan kesesuaian paling kecil terdapat di Kec. Cigudeg. Terdapat 13 kecamatan yang memiliki kesesuaian lebih dari $50 \%$ luas kecamatan, berturut-turut yaitu Kec. Cibinong, Bojong Gede, Gunung Putri, Cileungsi, Ciomas, Tenjolaya, Cisarua, Ciawi, Ciampea, Kemang, Cibungbulang, Caringin, dan Tamansari. Peta kesesuaian penggunaan lahan terhadap rencana pola ruang seperti pada Gambar 9. 
Tabel 1. Hasil Analisis Tumpang Susun Penggunaan Lahan terhadap Rencana Pola Ruang

\begin{tabular}{|c|c|c|c|c|c|c|c|c|}
\hline \multirow[b]{2}{*}{$\begin{array}{l}\text { Penggunaan } \\
\text { Lahan Tahun } \\
2015\end{array}$} & \multicolumn{7}{|c|}{ Arahan Pola Ruang } & \multirow[b]{2}{*}{$\begin{array}{l}\text { Jumlah } \\
\text { (ha) }\end{array}$} \\
\hline & $\begin{array}{l}\text { Kawasan } \\
\text { Hutan }\end{array}$ & $\begin{array}{c}\text { Kawasan } \\
\text { Pertanian } \\
\text { Lahan } \\
\text { Basah } \\
\end{array}$ & $\begin{array}{c}\text { Kawasan } \\
\text { Pertanian } \\
\text { Lahan } \\
\text { Kering } \\
\end{array}$ & $\begin{array}{l}\text { Kawasan } \\
\text { Perkebunan }\end{array}$ & $\begin{array}{c}\text { Kawasan } \\
\text { Permukiman }\end{array}$ & $\begin{array}{c}\text { Kawasan } \\
\text { Industri }\end{array}$ & $\begin{array}{l}\text { Tubuh } \\
\text { Air }\end{array}$ & \\
\hline Hutan & $31.426,40^{1)}$ & $141,92^{2)}$ & $635,58^{21}$ & $881,86^{2)}$ & $471,81^{2)}$ & 02) & $0^{2)}$ & $33.557,56$ \\
\hline Sawah & $7.330,47^{3)}$ & $19.919,35^{1)}$ & $5.769,31^{2)}$ & $6.307,65^{2)}$ & $27.747,13^{2)}$ & $703,12^{2)}$ & $388,95^{2)}$ & $68.165,98$ \\
\hline Tegalan & $9.071,12^{3)}$ & $2.091,20^{2)}$ & $6.867,06^{1)}$ & $6.558,07^{2)}$ & $14.435,70^{2)}$ & $525,71^{2)}$ & $40,70^{2)}$ & $39.589,57$ \\
\hline Perkebunan & $12.746,76^{2)}$ & $9.551,82^{2)}$ & $5.300,02^{2)}$ & $14.544,61^{1)}$ & $17.008,14^{2)}$ & $258,67^{2)}$ & $174,40^{21}$ & $59.584,43$ \\
\hline Permukiman & $1.500,78^{3)}$ & $4.090,06^{3)}$ & $2.293,02^{3)}$ & $2.344,82^{3)}$ & $38.076,84^{1)}$ & $2.091,99^{3)}$ & $58,29^{3)}$ & $50.455,80$ \\
\hline Industri & $454,33^{3)}$ & $32,99^{3)}$ & $287,18^{3)}$ & $503,88^{3)}$ & $1.509,63^{3)}$ & $1.285,73^{1)}$ & $8,73^{3)}$ & $4.082,47$ \\
\hline Tubuh Air & $17,16^{3)}$ & $0^{3)}$ & $8,79^{3)}$ & $49,50^{3)}$ & $291,73^{3)}$ & $2,46^{3)}$ & $2.373,47^{1)}$ & $2.743,11$ \\
\hline $\begin{array}{l}\text { Semak/Belukar/ } \\
\text { Lahan Kosong }\end{array}$ & $23.748,20^{2)}$ & $3.631,09^{2)}$ & $4.294,12^{2)}$ & $5.283,61^{2)}$ & $5.357,48^{2)}$ & $241,29^{2)}$ & $121,04^{2)}$ & $42.676,83$ \\
\hline Jumlah (ha) & $86.295,22$ & $39.458,43$ & $25.455,07$ & $36.474,00$ & $104.898,47$ & $5.108,98$ & $3.165,58$ & $300.855,75$ \\
\hline
\end{tabular}

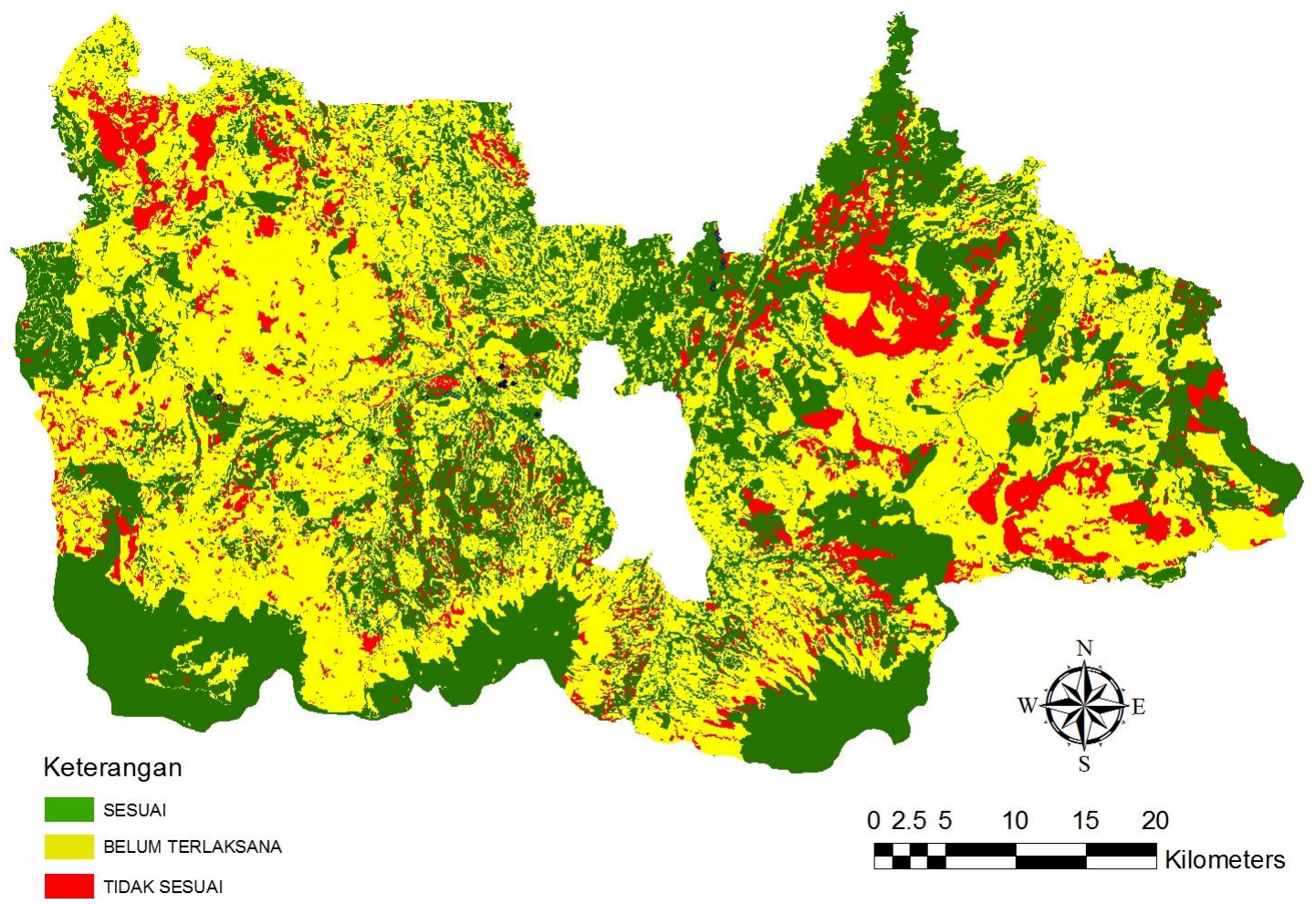

Gambar 9. Peta Kesesuaian Penggunaan Lahan terhadap Rencana Pola Ruang

Faktor-faktor yang Mempengaruhi Inkonsistensi Penggunaan Lahan terhadap Rencana Pola Ruang

Hasil analisis wawancara lapang diperoleh 7 (tujuh) variabel faktor-faktor yang mempengaruhi inkonsistensi penggunaan lahan terhadap rencana pola ruang. Berdasarkan frekuensinya secara berurutan faktor-faktor tersebut yaitu: kurangnya sosialisasi kepada masyarakat, tidak adanya perizinan, kebutuhan tempat tinggal, adanya fasilitas umum dan 
aksesibilitas, penggunaan lahan telah ada sebelum rencana pola ruang ditetapkan, berpindahnya kepemilikan lahan, dan fasilitas pertanian kurang mendukung (Tabel 2).

Tabel 2. Frekuensi Variabel Inkonsistensi Hasil Wawancara Lapang

\begin{tabular}{llcc}
\hline \multicolumn{1}{c}{${\text { Variabel Inkonsistensi }{ }^{1)}}^{\prime}$} & Frekuensi & Persentase $^{2)}$ \\
\hline a) Kurangnya sosialisasi kepada masyarakat & 20 & $74,07 \%$ \\
b) Tidak adanya perizinan & 19 & $70,37 \%$ \\
c) Kebutuhan tempat tinggal & 18 & $66,67 \%$ \\
d) Adanya fasilitas umum dan aksesibilitas & 14 & $51,85 \%$ \\
e) Penggunaan lahan telah ada sebelum rencana pola ruang ditetapkan & 13 & $48,15 \%$ \\
f) Berpindahnya kepemilikan lahan & 13 & $48,15 \%$ \\
g) Fasilitas pertanian kurang mendukung & 8 & $29,63 \%$ \\
\hline
\end{tabular}

Keterangan: ${ }^{1)}$ Diperoleh dari responden saat wawancara lapang, ${ }^{2)}$ Persentase dari 27 responden wawancara lapang

\section{Arahan Pengendalian Pemanfaatan Ruang}

Pengendalian pemanfaatan ruang menjadi fungsi yang wajib dilaksanakan pemerintah dalam tanggung jawabnya meningkatkan kesejahteraan masyarakat, mewujudkan keadilan, mengurangi konflik dan dampak negatif penataan ruang serta menjamin berlangsungnya pembangunan yang efisien, efektif serta sesuai dengan fungsi dan konsisten dengan RTRW (Kartika, 2011). Rumusan arahan pengendalian pemanfaatan ruang sebagai upaya untuk menekan pemanfaatan ruang agar sejalan dengan RTRW yang telah disusun, sehingga Kabupaten Bogor dapat menjalankan peran dan fungsinya dengan baik. Untuk saat ini pengendalian pemanfaataan ruang di Kabupaten Bogor baru menerapkan satu instrumen pengendalian yaitu perizinan, dimana Bappeda Kabupaten Bogor yang bertugas dalam monitoring dan pengawasan setiap lima tahun sekali mengadakan evaluasi perizinan terkait izin lokasi, Izin Perubahan Penggunaan Tanah (IPPT), dan Izin Mendirikan Bangunan (IMB). Untuk tiga instrumen lainnya masih belum dilaksanakan yaitu peraturan zonasi, insentif dan disinsentif, serta pengenaan sanksi.

Arahan pengendalian pemanfaatan ruang berdasarkan 4 instrumen pengendalian dan hasil penelitian yang dapat menjadi masukan bagi Pemerintah Daerah Kabupaten Bogor adalah sebagai berikut:

1) Perizinan yang sudah dilaksanakan selama ini perlu dilanjutkan dan ditingkatkan, salah satunya dengan membuat alur perizinan yang mudah dan transparan agar masyarakat bersedia mengurus perizinan terkait lahan dan bangunan. Selanjutnya perlu dilakukan pemantauan terhadap izin-izin yang telah dikeluarkan agar penggunaan lahan sesuai dengan peruntukan.

2) Perlu disusun segera Rencana Detail Tata Ruang berikut peraturan zonasinya, dengan mempertimbangkan: penggunaan lahan eksisting dan hak kepemilikan lahan yang telah dimiliki masyarakat; kawasan lindung baik yang berada dalam kawasan hutan maupun di luar kawasan hutan tetap dipertahankan fungsi dan penggunaan lahannya dan tidak diizinkan untuk dibudidayakan maupun dialihfungsikan; kawasan permukiman, industri, dan perkebunan, tidak boleh dibangun di luar area yang telah ditentukan kawasan peruntukannya. Sedangkan jika ada perubahan maka diperbolehkan sepanjang tidak mengganggu kawasan lain di sekitarnya.

3) Pemberian insentif dan disinsentif, yaitu: (a) Penggunaan lahan yang sudah sesuai dengan pola ruang RTRW dapat diberi insentif dengan pembangunan/pengembangan sarana prasarana wilayah, untuk daerah pertanian dapat diberikan fasilitas penunjang pertanian. (b) Rencana pola ruang yang belum terlaksana, maka penggunaan lahan diawasi dan diarahkan agar pemanfaatan ruang sesuai dengan peruntukannya. Hal ini 
dapat dilakukan dengan memberikan kemudahan perizinan, pembangunan/pengembangan sarana prasarana wilayah, serta keringanan pajak bagi pemanfaatan ruang yang sejalan dengan rencana pola ruang, sedangkan sebaliknya bagi pemanfaatan ruang yang tidak sejalan dengan rencana pola ruang. (c) Penggunaan lahan yang tidak sesuai rencana pola ruang maka penggunaan lahan tidak boleh dikembangkan luasan maupun bangunannya (jika berupa lahan terbangun), jika bersedia merubah penggunaan lahan sesuai dengan peruntukan maka dapat diberikan kompensasi berupa pembebasan biaya perizinan, ganti biaya kerugian, lahan pengganti untuk relokasi,serta pembangunan/pengembangan sarana prasarana wilayah.

4) Penggunaan lahan yang tidak sesuai terutama di kawasan lindung perlu diberi peringatan tertulis serta diarahkan untuk merubah penggunaan lahan sesuai rencana pola ruang. Jika tidak dilaksanakan maka dapat diberikan sanksi administratif, denda, kenaikan pajak atau pembongkaran bangunan (jika berupa lahan terbangun).

5) Perlunya sosialisasi kepada masyarakat terkait peraturan yang telah ditetapkan pemerintah. Selain itu perlunya pengawasan, monitoring dan evaluasi secara berjenjang dan berkala yang didukung kerjasama yang baik dari seluruh pihak baik dari pemerintah, masyarakat, swasta, maupun stakeholders lainnya.

\section{KESIMPULAN}

Penggunaan lahan di Kabupaten Bogor terdiri dari 8 jenis, yaitu sawah, perkebunan, permukiman, semak/belukar/lahan kosong, tegalan, hutan, industri, dan tubuh air. Penggunaan lahan yang dominan adalah sawah, perkebunan, dan permukiman. Jenis kepemilikan lahan terbesar berupa hak milik. Izin lokasi didominasi untuk peruntukan perumahan, bisnis dan usaha ekonomi, dan agrowisata. Kecamatan di Kabupaten Bogor sebagian besar tergolong dalam hirarki rendah (Hirarki III).

Sebagian besar penggunaan lahan sudah sesuai dengan pola ruang, baik yang berupa penggunaan lahan eksisting maupun yang masih belum terlaksana, sedangkan penggunaan lahan eksisting yang tidak sesuai hanya sebagian kecil.

Faktor-faktor yang mempengaruhi inkonsistensi penggunaan lahan terhadap rencana pola ruang yaitu kurangnya sosialisasi kepada masyarakat, tidak adanya perizinan, kebutuhan tempat tinggal, adanya fasilitas umum dan aksesibilitas, penggunaan telah ada sebelum rencana pola ruang ditetapkan, berpindahnya kepemilikan lahan, dan fasilitas pertanian kurang mendukung.

Arahan pengendalian pemanfaatan ruang adalah dengan menerapkan 4 instrumen pengendalian baik yang sudah dilaksanakan maupun yang belum dilaksanakan selama ini, yaitu perizinan, peraturan zonasi, pemberian insentif dan disinsentif, dan pemberian sanksi. Selain itu perlunya sosialisasi kebijakan serta pengawasan, monitoring dan evaluasi secara berjenjang dan berkala.

\section{DAFTAR PUSTAKA}

Bakar, S. (2008) Kelembagaan Pengendalian Pemanfaatan Ruang di Daerah. Buletin Online Tata Ruang, MeiJuni 2008. Diperoleh dari http://penataanruang.pu.go.id/bulletin/ pada tanggal 4 April 2016.

Barus, B., Panuju, D.R., Iman, L.S., Trisasongko, B.H., Gandasasmita, K., dan Kusumo, R. (2011) Pemetaan Potensi Konversi Lahan Sawah dalam Kaitan Lahan Pertanian Berkelanjutan dengan Analisis Spasial. Dlm: Ariyanto, D.P., Dewi, W.S., dan Suwardi (Ed.) (2011) Prosiding Seminar dan Kongres Nasional Himpunan Ilmu Tanah Indonesia X (Tanah Untuk Kehidupan yang Berkualitas); 6-8 Desember 2011; Surakarta, Indonesia, hlm. 554-561. Surakarta: Jurusan Ilmu Tanah, Fakultas Pertanian, Universitas Sebelas Maret Surakarta dan Himpunan Ilmu Tanah Indonesia.

Dewi, I.A. (2011) Efektifitas Tata Ruang sebagai Instrumen Pengendalian Perubahan Penggunaan Tanah Sawah menjadi Penggunaan Non Pertanian di Kabupaten Bekasi. Dlm: Ariyanto, D.P., Dewi, W.S., dan Suwardi (Ed.) (2011) Prosiding Seminar dan Kongres Nasional Himpunan Ilmu Tanah Indonesia X (Tanah Untuk Kehidupan yang Berkualitas); 6-8 Desember 2011; Surakarta, Indonesia, hlm 1005-1011. Surakarta: 
Jurusan Ilmu Tanah, Fakultas Pertanian, Universitas Sebelas Maret Surakarta dan Himpunan Ilmu Tanah Indonesia.

Djakapermana, R.D. (2008) Rencana Tata Ruang Kawasan Jabodetabekpunjur: Upaya Menyeimbangkan Pertumbuhan Ekonomi Dengan Kelestarian Lingkungan Hidup. Buletin Online Tata Ruang, JuliAgustus. Diperoleh dari http://penataanruang.pu.go.id/bulletin/ pada tanggal 4 April 2016.

Fajarini, R., Barus, B., dan Panuju, D.R.. (2015) Dinamika Perubahan Penggunaan Lahan dan Prediksinya untuk Tahun 2025 serta Keterkaitannya dengan Perencanaan Tata Ruang 2005-2025 di Kabupaten Bogor. Jurnal Tanah dan Lingkungan 17(1), 8-15.

Firman, T. 2004. Major issues in Indonesia's Urban land Development. Land Use Policy 21, 347-355.

[Kanwil. BPN Prov. Jawa Barat] Kantor Wilayah Badan Pertanahan Nasional Provinsi Jawa Barat (2013) Neraca Penatagunaan Tanah Kabupaten Bogor. Bandung: BPN Provinsi Jawa Barat.

Kartika, I.M. (2011) Pengendalian Pemanfaatan Ruang. GaneC5(2), 123-130.

Kurnianti, D.N. (2015) Proyeksi Penggunaan Lahan untuk Konsistensi Tata Ruang di Kawasan Jabodetabek . Tesis, Sekolah Pascasarjana. Institut Pertanian Bogor.

Mansur, Y,H. (2015) Analisis Sosio-Agraria dan Konversi Lahan serta Strategi Perlindungan Lahan Sawah di Kota Sukabumi. Tesis, Sekolah Pascasarjana. Institut Pertanian Bogor.

Mayasary, D.S. (2015) Analisis Perubahan Penggunaan Lahan, Pola Ruang dan Tingkat Perkembangan Wilayah di Kota Bogor. Skripsi, Departemen Ilmu Tanah dan Sumberdaya Lahan, Fakultas Pertanian. Institut Pertanian Bogor.

Panuju, D.R. dan Rustiadi, E. (2013) Teknik Analisis Perencanaan Pengembangan Wilayah. Bogor: Lab. Pengembangan Wilayah, Departemen Ilmu Tanah dan Sumberdaya Lahan, Institut Pertanian Bogor.

[Pemda. Kab. Bogor] Pemerintah Daerah Kabupaten Bogor (2016) Website Resmi Kabupaten Bogor. Diperoleh dari https://bogorkab.go.id pada tanggal 4 April 2016.

Zain, A.F.M., Syahban, G., Ermyanyla, M. (2013) Analisis Perubahan Peruntukan Lahan Pertanian Perkotaan (Urban Agriculture) menjadi Non Pertanian di Kota Depok. Dlm: Rustiadi, E., Dadang, Aisyah, S.I., Arifin, N.H.S., Syukur, M., Williams, F., Suwardi, Nasrullah, N., dan Pudjianto (Ed.) (2013) Prosiding Lokakarya Nasional dan Seminar Forum Komunikasi Perguruan Tinggi Pertanian Indonesia (FKPTPI); 2-4 September 2013; Bogor, Indonesia, hlm 484-498.Bogor: Fakultas Pertanian, Institut Pertanian Bogor. 